\title{
Anna Kingsford and the Intuitive Science of Occultism
}

\author{
Christine Ferguson | ORCID: 0000-0002-2261-6290 \\ University of Stirling, Stirling, Scotland, UK \\ christine.ferguson@stir.ac.uk
}

\begin{abstract}
Feminist, anti-vivisectionist, occultist, and one of the first British women to qualify as a medical doctor, Anna Kingsford remains notably absent from recent studies of Victorian science and spiritualism. Her efforts to synthesize occult and scientific worldviews have been side-lined by those of male contemporaries such as Oliver Lodge and Alfred Russel Wallace, ones whose professional status and gender coordinates more readily align with implicit assumptions about the kind of person for whom disenchantment posed an intellectual problem that might best be solved in the laboratory. My paper positions Kingsford at the very heart of the late Victorian project to accommodate scientific innovation and spiritual belief by tracing her attempts to forge an intuitive epistemology superior to what she viewed as the deeply suspect championship of objectivity. In doing so, it aims to expose and redress blind spots within recent esotericism studies-based approaches to the disenchantment debate.
\end{abstract}

\section{Keywords}

Anna Kingsford - disenchantment - intuition - occultism - women in medicine feminist epistemology of science

\section{Breaking into the Laboratory: Two Apocryphal Stories}

The month is December 1877 , in a frigid teaching theatre operated by the Université de Paris' prestigious medical faculty. The winter gloom is only deepened by the shrieks of the animal — a rabbit, maybe, or a dog-whose entrails are being meticulously laid open in demonstration for the assembled watchers. 
Suddenly, a woman strides in; she is radiantly, almost preternaturally beautiful, a fact that seems to fill her fellow, and almost exclusively male, medical students - for she is one of them - with even more rage than her infringement on their hitherto exclusively masculine place of study. Approaching the lecturer, she offers him a bargain as startling as it is abominable; if you vow never to operate on living animals again, she proposes, I'll let you vivisect me in their place, on this table and fully conscious. The room explodes in uproar. ${ }^{1}$

Almost a decade later, the same woman, now a qualified M.D., stands outside the Pasteur Laboratory at 45 Rue d'Ulm, her face a mask of pained concentration. Inspired by what she believed to have been her successful assassinations of the physiologists Claude Bernard and Paul Bert by thought power, she has come here tonight, accompanied by her magical partner Edward Maitland, to eliminate France's great vaccination pioneer and thus fulfil her earlier vow to 'make it dangerous, nay deadly, to be a vivisector.'2 On this occasion, however, it would be she who was fatally harmed. Not on site, Pasteur evaded the psychic attack that Kingsford launched against him. A sudden downpour forced her to abort her mission and drenched her through, triggering a new bout of pneumonia in her already failing lungs. Within a year, she would be dead, while the still very much alive Pasteur was free to continue his vivisectional work and reap the rewards of his revolutionary bacteriological career.

The woman, of course, is Anna Kingsford (1846-1888), the remarkable novelist, feminist campaigner, anti-vivisectionist, editor, fashion columnist, occultist, and visionary who became one of the first ever British women to qualify as a medical doctor (See Figure 1). Despite this formidable and varied body of accomplishments, these vignettes - typically offered without scrutinyremain the best-known, and most notorious, episodes of her career. ${ }^{3}$ She is virtually absent from the historiography of British women's entrance into the medical profession, and until recently was perpetually overshadowed in accounts of modern female occultism by the likes of H.P. Blavatsky, Dion Fortune, and the women of the Hermetic Order of the Golden Dawn. ${ }^{4}$ She has

1 For a fuller, albeit unverified, account of Kingsford's plan to offer herself up as vivisectional subject in exchange for a cessation of animal experimentation, see: Maitland, Anna Kingsford: Her Life, Letters, Diary, and Work, I, 257.

2 Maitland, Anna Kingsford, I, 258.

3 See for example a 1996 Scientific American article which reduces Kingsford's entire medical school career to a psychic assassination plot: 'she spent most of her time in Paris, directing her energies into killing Bernard (and other high-profile physiologists, such as Paul "the Bends" Bert) with thought waves.' Burke, 'What Goes Around Comes Around', 126.

4 There are signs that this situation may be about to change, including a 2018 conference dedicated to her life and work that was held at the London Theosophical Society. 


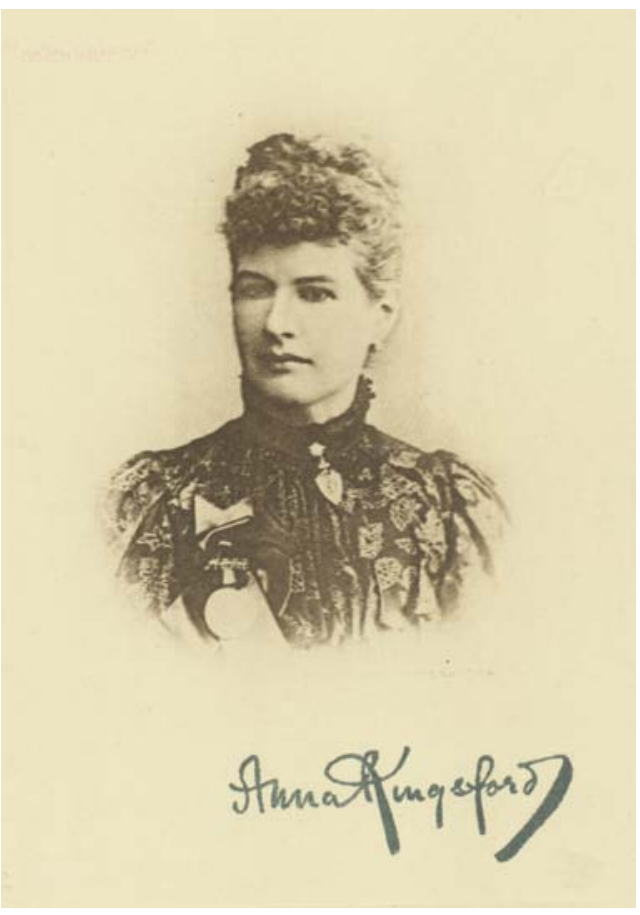

FIGURE 1

Signed photograph of Anna Kingsford MAITLAND, ANNA KINGSFORD. REPRODUCED WITH PERMISSION OF THE NATIONAL LIBRARY OF SCOTLAND

received slightly more attention from scholars of the nineteenth-century animal rights movement, but not yet at the level warranted by her impassioned and enduring commitment to the cause; no scholarly biography of Kingsford currently exists. ${ }^{5}$ What persists are these two tall tales of a woman trying desperately to break into a laboratorial space through physical and mental force, in attempt to act as agent of justice and vivisectional subject.

Both, it must first be said, are apocryphal and deserve far more scrutiny than they have hitherto received. They derive from the same, suspect source: the astonishingly self-aggrandizing biography Anna Kingsford: Her Life, Letters, Diary, and Work (1896) published by Maitland after he had destroyed all of his subject's papers, and written to emphasize his own indispensability to a woman no longer present to defend herself. Positioning himself as white knight, he here explains how he dissuaded Kingsford from the vivisectional stunt (apparently disclosed only to him) lest it fuel the practice she sought to abolish; so too does he narrate Kingsford's own death as karmic consequence of her sincere psy-

5 See references to Kingsford's anti-vivisection work in Lansbury, The Old Brown Dog, Viswanathan, '“Have Animals Souls?"'; Traini, The Animal Rights Struggle. 
chic campaign against Pasteur. If these stories remain uncontested, it is perhaps because they align so well with a vision of Kingsford as a woman who, if scientifically trained and credentialled, was never herself of science, a figure whose adoption of occult beliefs and spiritualist practices is unworthy of the comment, or the careful explanation as response to a specific intellectual crisis or problem, they attract in regards to male scientific converts such as Oliver Lodge, William Crookes, Alfred Russel Wallace, and others. Rather than these (ultimately moot) stories, it is this exclusion of Kingsford from the purview of contemporary spiritualism and science studies, and from the larger disenchantment debate, that I seek to challenge. I will use the case of Kingsford to ask why scientific women are still so often left out of our account of naturalism's engagement with esotericism, a near-total elision that cannot be accounted for by their relative scarcity within late nineteenth and early twentieth-century professional institutions alone. I will proceed by extracting from Kingsford's occult and medical writings an increasingly coherent spiritual-scientific philosophy, one representative of an important and specifically gendered response to what Egil Asprem has called 'the problem of disenchantment'; I will also show how and why a greater attention to scientifically-trained women might produce a more complex and robust understanding of the relations between science and esotericism in modern Britain. ${ }^{6}$ The brand of intuitive occult science which I will attribute to Kingsford has for too long been absent from our discussions of if, when, and for how long, the West was ever disenchanted. Within her evolving esoteric scientific worldview, the investigator and the experimental subject were not separate, but rather one; the pursuit of knowledge, whether scientific or spiritual, required not the adoption of the so-called 'view from nowhere' demanded by objectivity, but rather an embrace, interrogation, and amplification, of the self. ${ }^{7}$

From the 1970s onwards, the historiography of science and spiritualism has developed under the long shadow of Max Weber's highly influential if much challenged-indeed, primarily influential now through its persistent rebuttal-disenchantment thesis. Articulated in works such as Die Protestantische Ethik und der Geist des Kapitalismus (1904-1905) and 'Wissenschaft als Beruf'

6 Asprem, The Problem of Disenchantment, 6.

7 For more on the significance of the 'view from nowhere' to the history of scientific objectivity, see: Potter, 'Feminist Epistemology and the Philosophy of Science', 237. 
(1918/22), this sociological theory characterized Western modernity as both a period and project of disenchantment, one in which scientific rationality had become epistemologically dominant by successfully pushing non-secular, spiritual, and magical beliefs to the cultural margins. ${ }^{8}$ If this process had not necessarily increased the happiness or intelligence of average Westerners, it had fundamentally reshaped their understanding of what and how they could expect to know. What Weber described as ' $[t]$ increased intellectualization and rationalization' of life in the West entailed

the knowledge or belief that if one but wished one could learn it at any time ... it means that principally there are no mysterious incalculable forces that come into play but rather that one can, in principle, master all things by calculation. This means that the world is disenchanted. ${ }^{9}$

This expansion of the knowable was coextensive with a similar restriction of the kind of questions to which science could be applied: for Weber, it could not be applied to questions of value. 'Whether life is worth while living and whenthis question is not asked by medicine,' he asserts. 'Natural science gives us an answer to the question of what we must do if we wish to master life technically. It leaves quite aside ... whether we should and do wish to master life technically and whether it makes sense to do so.'10 Such concerns should be detached from the pursuit of scientific empiricism and relegated to the realms of philosophy, theology, and personal belief.

Over the last fifty years, a surge of scholarship on the occult commitments and spiritualist pursuits of leading European scientists-Alfred Russel Wallace, Oliver Lodge, William Crookes, Charles Richet—has implicitly chipped away at the disenchantment thesis, many, if not all, operating through the mode of micro-historical case study. ${ }^{11}$ More recently, the turn of the millennium ushered in a new wave of science and spiritualism studies willing to make that critique in a more explicit and expansive mode - key here is the work of Richard Jenkins, Roger Luckhurst, Victoria Nelson, Michael Saler, Joshua Landy, Egil Asprem,

$8 \quad$ Published first in essay form in between 1904-1905, Die protestantische Ethik und der Geist des Kapitalismus was translated and published in English as The Protestant Ethic and the Spirit of Capitalism (1930); Wissenschaft als Beruf' was translated as Science as Vocation in 1946.

9 Weber, 'Science as Vocation', 117.

10 Weber, 'Science as Vocation', 122.

11 See for example Kottler, 'Alfred Russel Wallace, the Origin of Man, and Spiritualism'; Palfremen, 'Between Scepticism and Credulity'; Shortt, 'Physicians and Psychics'; Oppenheim, The Other World; Sera-Shriar, 'Credible Witnessing'. 
Jason Josephson-Storm, Courtenay Raia, and Richard Noakes. ${ }^{12}$ Collectively if by no means for the same reasons, these studies challenge Weber's presentation of the magnitude, endurance, or even initial occurrence of disenchantment. Jenkins, for example, accuses Weber of presenting an overly-coherent and unconvincingly dichotomized account of the past and present West, one that simultaneously under-reckons the persistence of magical beliefs and overreckons public faith in science. Importantly, such critiques do not for Jenkins require a wholesale abandonment of the disenchantment hypothesis, only a greater scepticism about its extent. ${ }^{13}$

Other scholars have been less careful.Victoria Nelson, for example, contends that such a blanket process of disenchantment did indeed occur, and with suspiciously remarkable precision, sometime around the year 170o, only to be then rescinded within the Western collective unconscious through fantastical forms of cultural production. ${ }^{14}$ Disregarding the scores of writers, artists, and scientific naturalists who very deliberately and consciously engaged with psychical and spiritualist phenomena over the last three centuries, her study renders the barrier between science and art, secularism and belief, absolute:

[ $t$ ] he rise of empirical science and pigeonholing of intellectual disciplines during the nineteenth and twentieth centuries would displace gnosis from its role as the prism of truth through which to view the entire cosmos into merely one of many fictive prisms of the imagination within the realm of art. ${ }^{15}$

Equally reluctant to deal with sincere and consciously-adopted esoteric beliefs - which they equate with 'naivete, irrationalism, or hypocrisy' - Joshua Landy and Michael Saler contend that the real re-enchantment of the world can be seen in modern intellectual and artistic cultures which embrace 'fully secular strategies for rediscovering at-homeness in the world, order, necessity, intensity, wonder and the infinity' in order to 'satisfy again all the pressing demands formerly satisfied by religion. ${ }^{16}$ Note here the heavy lifting being performed by the word 'formerly.' Their account seeks to establish a newly san-

\footnotetext{
12 Jenkins, 'Disenchantment, Enchantment, and Re-Enchantment'; Nelson, The Secret Life of Puppets; Luckhurst, The Invention of Telepathy; Saler \& Landy, eds. The Re-Enchantment of the World; Asprem, The Problem of Disenchantment; Josephson-Storm, The Myth of Disenchantment; Raia, The New Prometheans; Noakes, Physics and Psychics.

13 Jenkins, 'Disenchantment, Enchantment, and Re-Enchantment', 13.

14 Nelson, The Secret Lives of Puppets, 43.

15 Ibid., 28.

16 Landy and Saler, 'Introduction', 14.
} 
itized, affective rather than magical, form of enchantment predicated on an alleged recession of religion from public and personal life in the West-one whose evidence, at my time of writing in 2021, admittedly seems underwhelming. In any case, actual supernatural belief, whether traditional or new, has no place in the respectable, because largely aesthetic, re-enchantment processes through which Landy and Saler contest Weber.

Perhaps the lack of consensus around what dis- or re-enchantment might comprise, or who should be recognized as their representatives, explains another odd feature of the recent disenchantment debates: a tendency for some scholars to present the discursive field as terra nullius, in which they alone are the first to question an otherwise universal assent to Weber ${ }^{17}$ We see this move in the introduction to Jason Josephson-Storm's compelling and original study of the scientific-occult interface from the seventeenth century to the present day, which asserts 'The single most familiar story in the history of science is the tale of disenchantment ... I am here to tell you that as broad cultural history, this narrative is wrong.' ${ }^{18}$ While the author admits that 'historians of spiritualism know different,' he presents them as a lone exception to the 'most scholars' who would be surprised to learn that Marie Curie ever attended a séance. ${ }^{19}$ This odd formulation significantly under-reckons the cross-disciplinary impact of the last 50 years of spiritualist historiography, one whose findings have transformed literary and cultural studies, the history of science, art history, and media studies, to name just a few.

As this brief review has shown, the story that scholars tell about disenchantment-and their critical self-positioning as germinal truth-tellers-depends very much on the cast of historical characters they choose to map patterns of cultural change. If it has been easy for some to over-state the cultural saturation of disenchantment (or its opposite) in order to then puncture it, to validate some forms of fantasy or mystical yearning as culturally relevant while dismissing others, it is perhaps because they come to the territory pre-equipped with a priori ideas about who might count as a dis-enchanted subject. And what the studies cited above share, regardless of their differing responses to Weber, is their near total omission of scientific women. ${ }^{20}$ In most of this scholarship,

17 For another example of this form of historiographical erasure, see Raia's The New Prometheans, a 2019 study which opens by asserting that the wider academic community, here referenced as "we," continues to 'dismiss out of hand' Victorian psychical researchers, and insist that they were either 'duped, delusional, or dishonest' (8).

18 Josephson-Storm, The Myth of Disenchantment, 3.

19 Ibid., 2.

20 The studies by Noakes and Josephson-Storm are only partial exceptions to this tendency. 
women remain underrecognized for their role in promoting scientific naturalism through sceptical engagements with psychical investigation, and their adoption of occult belief or pursuit of spiritualist investigation is treated as irrelevant to the larger cultural fortunes of science, even as it has been central to the historiography of esotericism. This continual marginalization risks implying that such women had no rationality to lose, or were always-already spiritual in a way that renders their enduring or renewed commitment to supernatural beliefs simply irrelevant to disenchantment as a phenomenon of modernity. Egil Asprem explains the almost exclusively male focus of his study of 'new natural theologies' in the late Victorian scientific community as a reflection of 'the heavily gendered nature of the academic professions at the turn of the century,' but this stipulation too quickly glides over the cases of women like Kingsford, Curie, and Sidgwick who were scientifically trained and accredited; if their numbers were small, they were by no means non-existent, and closer archival investigation would no doubt provide many more examples of Victorian and Edwardian scientific women for whom the larger cultural drift to disenchantment also represented, as Asprem so usefully frames it, a problem solvable without any necessary intellectual sacrifice. ${ }^{21}$ Such discoveries are only possible if one first accepts that there might be something worth looking for. If, however, we confine our understanding of disenchantment's main constituency to the elite, gentlemen attendees of London's X-Club, it will remain not only all male, but also vanishingly small. To minimize the role of women in addressing the problem of disenchantment is to risk perpetuating the legacy of historical exclusion which made it so difficult for figures like Kingsford to access scientific training in the first place. In what follows, I place Kingsford within the historical and conceptual space of the enchanted laboratory—not to legitimize her often dubious, even dangerous, scientific claims, but to render her and others like her visible as key players within a newly-complex understanding of the spread and resistance to scientific authority at the end of the nineteenth century. ${ }^{22}$ Disenchantment was never just men's business; women entered its lists,

The latter opens with a rare scene of a scientific woman-in this case, Marie Curieat a spiritualist séance with Eusapia Palladino. This remarkable encounter between two women at seemingly opposite ends of the spiritualism and science spectrum is not developed into one of the book's core case studies. More attention is paid to Eleanor Sidgwick and Alice Johnson in Noakes's Physics and Psychics, although not to the same extent as William Fletcher Barrett, William Crookes, or Oliver Lodge.

21 Asprem, The Problem of Disenchantment, 76 and 200.

22 Most notably her vehement and spiritually-situated resistance to vaccination, one whose influence on subsequent forms of New Age anti-vaccinationism urgently requires further study. 
not simply as experimental tests subjects or strategically passive vessels, but as engaged problem solvers.

\section{Anna Kingsford in the Scientific Public Sphere}

Anna Kingsford occupied an unparalleled position within the sometimes overlapping late Victorian public spheres of medicine, political activism, and occultism. A wealthy social elite whose early financial independence allowed her to doggedly pursue the medical training unavailable to poorer women, she had no need to pursue the empowerment-through-passivity strategy so influentially attributed to female mediums in Alex Owen's The Darkened Room (1989). ${ }^{23}$ When Kingsford wanted to enter into a prominent medical debate, she could, rather than performatively channelling a distinguished dead doctor, as the American medium Cora L.V. Scott did Benjamin Rush, write directly to high-profile press venues such as the Times, the Standard, the Pall Mall Gazette under her own name and sign herself 'M.D. ${ }^{24}$ While she does not appear to have published in any of the London medical journals - a fact potentially attributable to her bête noire status within the contemporary medical establishment as both woman and anti-vivisectionist-she certainly subscribed to and read them; her articles for respectable generalist periodicals such as Nineteenth Century are littered with reference to them. Like the other, and far betterknown, fiction-writing spiritualist doctor who would follow in her wake-Sir Arthur Conan Doyle (1859-1930) — she had by the end of her life established a dual presence in Britain's spiritualist and mainstream press and was respected by both. ${ }^{25}$ Indeed, the medical opinions she advanced in the secular press were routinely received and framed as legitimate contributions to still open phys-

23 Kingsford was born in Stratford in 1846, the last of twelve children produced by successful London shipowner John Bonus and his wife Elizabeth Ann Schröder. When her father died in 1865 , she came into the considerable annual income of approximately $£ 888$ (Pert 19), thus allowing her the financial freedom open to few other women of her generation.

24 See for example Kingsford, 'The Uselessness of Vivisection'; Kingsford, 'Dr John Hughes'; Kingsford, 'Surgery and Vivisection'; Kingsford, 'M. Pasteur's "Cure” of Hydrophobia'; and Kingsford, 'The Sweating Cure for Hydrophobia.'

25 The respect typically accorded to Kingsford in the mainstream press no doubt owes much to the fact that, at the time of her death in 1888, Maitland's scandalous two-volume biography was still eight years away from publication; her psychic assassination plot, and claims to receive reincarnated selves and the naked spirits of Greek gods in her rooms at night were not yet known. For examples of her contributions to the spiritualist press, see: Kingsford, 'Animals and their Souls'; Kingsford, 'Diet: Its Moral and Spiritual Aspects'; and Kingsford, 'Violationism' or Sorcery in Science'. 
iological debates, no matter how incorrect, and indeed injurious, we know some of them to be today (e.g. her vehement insistence that rabies was better treated via water bath and sweating than by animal-tested vaccination). Indeed, responding to her rebuttal of Louis Pasteur's newly-announced inoculative treatment of hydrophobia, the Edinburgh Evening News describes her as one of the 'ablest lady doctors' and expresses in conclusion only the wish that 'the profession would come to some agreement on the subject.'26 While this sentiment might strike us as damning in its faint praise, it stands as a veritable paean when contrasted with the misogynist vituperation launched against her by continental physiologists such as F. Borel and Henri Kleffler who accused her of either buying her degree or, as a woman, lacking the mental nous to understand the rational arguments in favour of vivisection. ${ }^{27}$

The route into this position of authority was by no means an easy one for Kingsford, and its rigors surely helped to foster the methodological orientation which would later bridge her scientific and occult thinking, namely an intuitive and necessarily self-focused one which challenged both the achievability and desirability of the 'creed of objectivity' then ascendant, as Lorraine Daston and Peter Galison write, within 'every aspect of science. ${ }^{28}$ This objectivity, they contend, was designed specifically to oppose anti-rationalist and faulty modes of observation and data interpretation. Nonetheless, as both Egil Asprem and Richard Noakes have shown, the signature methods and standpoints associated with objectivity were by no means exclusive to an antispiritualist worldview; both the late Victorian spirit medium and the objective scientific naturalist were urged to suspend their own experiences, emotions, and agendas to become, at least in principle, a neutral recording instrument of their target phenomena. ${ }^{29}$ From the mid-nineteenth century onwards, Daston and Galison write, 'men of science began to fret about a new kind of obstacle to knowledge - themselves. ${ }^{30}$ To counteract the vagaries of their own subjectivity, 'scientists strove for a self-denying passivity, which might be described as a will to willessness. The only way for the active self to attain the desired receptivity to nature was to turn its domineering will inward - to practice selfdiscipline, self-restraint, self-abnegation, self-annihilation, and a multitude of other techniques of self-imposed selflessness. ${ }^{31}$ This description echoes Alex

\footnotetext{
$26 \quad$ Kingsford, 'Cures for Hydrophobia', 3.

27 See Traini, The Animal Rights Struggle, $155^{-156 .}$

28 Daston and Galison, Objectivity, 195.

29 Asprem, The Problem of Disenchantment Discourse; and Noakes, Physics and Psychics.

30 Daston and Galison, Objectivity, 34.

31 Ibid., 203.
} 
Owen's famous account of spirit channelling as a form of 'renunciation of self' in which the medium gained power through 'her ability to absent herself.' ${ }^{32}$ Naturalists and spiritualists were arguably never more alike in the latter half of the nineteenth century than in their professed desire to remove their personal selves from the process of investigation. Importantly, however, Kingsford, showed little interest in this form of personal erasure in either her medical or esoteric pursuits. Her professional identity and indeed, recovered past life memories, had been too hard earned to abandon so dramatically. She would campaign to install, not just her current personality, but also multiple reincarnative identities, as privileged epistemic agents.

Before explicating the subjectivist convictions that played out in Kingsford's spiritual-scientific thinking, it is worth revisiting my earlier caveat about what remains the most significant source on her life: Maitland's posthumous biography. Kingsford's platonic magical partner and medical school chaperone, Maitland appears in the pages of this book as a pathological narcissist of monumental proportions; for example, he at one point unabashedly declares that his own arcane writings could surpass and reduce to obsolescence the entire contents of the British Museum Library, rendering them 'no longer of value. ${ }^{33} \mathrm{He}$ features also as a jealous and peevish companion liable to characterize Kingsford's occasional episodes of coolness towards, or disagreement with, him as the result of demonic possession. ${ }^{34} \mathrm{~A}$ man of such grandiose levels of selfesteem can hardly be expected to focus on subjects other than himself exclusively or for too long, and indeed, so full is Maitland's Anna Kingsford of the account of Maitland's own spiritual development that we might justly accuse it of being mistitled. Furthermore, we have little way of determining the accuracy of Maitland's version of Kingsford, as he burned all her remaining papers after publishing it. ${ }^{35}$ For some commentators, particularly those invested in extolling Kingsford's spiritual legacy, these gaps and biases are sufficient to completely invalidate the source, or at least its account of those episodes most likely to besmirch her reputation as a learned, rational, and ethical woman. Thus, Alan Pert, commenting on Maitland's account of Kingsford's planned auto-vivisectional sacrifice and psychic murder plot, concludes it is inconceivable that an intelligent woman like Anna would contemplate such an idea for a second,' adding that, after all, 'there is no reliable evidence that one can kill

\footnotetext{
32 Owen, The Darkened Room, 10, 12.

33 Maitland, Anna Kingsford, I, 100.

34 Ibid., I, 243.

35 Pert, Red Cactus, 3.
} 
others by mind power alone. ${ }^{36}$ True, but neither is there reliable evidence that rabies can be cured with a hot bath. There is no necessary reason why an intelligent woman of the 188 os would be less inclined to believe one rather than the other. Pert's objections should give us pause, but are insufficient to entirely disqualify Maitland's book as a guide to Kingsford's intellectual-spiritual development. We might justify its use, albeit with care, for the reasons that some, if not all, of its factual claims are externally verifiable, and that there is, as we will now see, a demonstrable continuity between the epistemological and ontological positions it ascribes to Kingsford and those she adopted in her own published writings. These connections are nowhere more apparent than in her advocacy of the value of situated subjectivity in scientific and occult study.

Towards a Self-ish Spiritualist Science

Medical school was not easy for any of the women who struggled to enter its precincts in the 1870 os. $^{37}$ They routinely suffered harassment, legal restriction, physical abuse, and, in some cases, quite literally had filth thrown at them as they attempted to enter their chosen profession. ${ }^{38}$ For Kingsford, it was hell on earth. Like Sophia Jex-Blake and Elizabeth Garrett Anderson before her, she was compelled to travel to the Université de Paris for her studies, as no British university would then award women medical degrees. She matriculated in 1874, entering the programme at a high-water mark for the antivivisection campaign whose lists she had entered and whose cause formed her hidden motive for application. In an early letter to Maitland, she explained that she wanted to 'ente[r] the profession - not for the sake of practice, but for scientific purposes;' this purpose, she later declared, was 'to prove that a diploma can be obtained without having witnessed a vivisectional experiment. ${ }^{39}$ Her eventual success came at a considerable cost to her finances and nerves. Kingsford was forced to keep replacing her tutors when they refused

$36 \quad$ Ibid., 199, 202.

37 For accounts of the women's campaign for medical education in Britain, see Bell's Storming the Citadel; Mary St. John Fancourt's They Dared to be Doctors; Bonner's To the Ends of the Earth; and Roberts' Sophia Jex-Blake: A Woman Pioneer in Nineteenth-Century Medical Reform.

38 Witness the Edinburgh Surgeon's Hall Riot in 1870, in which the 'Edinburgh 7' - a group of 7 female students were attacked and pelted with filth by their male counterparts and members of the general public as they attempted to attend an anatomy exam.

Maitland, Anna Kingsford, I, 28 and 75 . 
to teach her without vivisectional demonstration; she was also plagued by ill health, constantly leered at and harassed by her fellow students and tutors alike, and physically barred from entering a post-mortem room by an instructor appalled at the prospect of teaching anatomy to a woman. ${ }^{40}$ Eventually, Maitland claimed that she was forced off campus altogether, as 'the laboratories were in such close proximity to the lecture-rooms that the cries of the animals under torture were plainly audible, and were so distressing as to compel her to give up her attendance and have recourse to private tuition.41 Isolated, ill, and often exhausted, Kingsford appears to have fallen into a state of deep melancholia and even paranoia. Maitland records that, despite being a mother herself, she came to develop an ante-natalist contempt for pregnant women who she reviled for bringing more children into a miserable race, and to suspect some of her lecturers of conducting secret medical experiments on orphans. ${ }^{42}$

Beyond the mundane incidents of bullying and abuse that were sadly all too common for female medical students in the eighteen-seventies, Kingsford faced a rather more unique form of torment: namely, black magical attack. Maitland's biography presents the Université de Paris as a veritable hotbed of diablerie in which Kingsford's misogynist academic opponents summoned demonic assistance to persecute and seduce her. One professor, identified first only as 'Monsieur O' and then later code-named 'Apollyon,' is said to have used his magical powers to force Kingsford under his thrall, and then send a malevolent entity to taunt her on a nightly basis. ${ }^{43}$ O's motives are in Maitland's presentation strictly lecherous, a fact he claims to have had confirmed in a séance with the American medium John William Fletcher. Here Fletcher's spirit guide Winona stated '[Kingsford] likes his attention, and excites him by her womanhood and puts him in a frenzy. ${ }^{\prime 4}$ Anna Kingsford states that its subject eventually succeeded in throwing off O's baleful influence, but asserts that this would not be her last encounter with black magic within the Faculté. She is later claimed to have encountered a 'practical student of occult science' on staff who confirmed that Claude Bernard, the great pioneer of scientific objectivity, was himself 'one of the few French savants who took an interest in occult science,' although he apparently lacked the occult credentials to fend off the fatal psychic attack which, according to Maitland, Kingsford successfully launched

\footnotetext{
$40 \quad$ Ibid., $78,65,15^{2}$.

41 Ibid., 78.

42 Ibid., 178, 342.

43 Ibid., 212.

44 Ibid., 227.
} 
against him. ${ }^{45}$ Maitland reports that, upon hearing of Bernard's death from undisclosed causes in February 1878, Kingsford sat on the steps of the École de Médecine and declared: 'It has been strongly borne in on my mind that I have been the means of this, and that he has indeed came to his death through my agency ... if it prove that that I really possess such a glorious power, woe be to the torturers! God willing, what a murrain here shall be upon them!'46

While it is perfectly possible that that these stories were the products of Maitland's jealous invention or fantasy, Kingsford did in her own writings link vivisection to black magic, insisting that the soul of the experimenter always became entangled — in this case, destructively — with the object and method of his investigation. She kept such views under wraps during the course of her degree study, but became much more publicly vocal about the deleterious magical effects of vivisection, and about her spiritualist beliefs, after her M.D. was safely conferred. In 'Violationism, or Sorcery in Silence,' a lecture delivered to the British National Association of Spiritualists in 1882 and then published in Light, she aligned the practices of the experimental physiologist with those of the medieval sorcerer. Far from being calm, emotionally detached, and objective in their proceedings, she insisted, vivisectionists actually received sensual delight from offering bloody tribute to the dark forces they served. '[T]he vivisector of to-day,' she writes, 'is in fact a practitioner of black magic, the characteristic cultus of which has been described by a wellknown writer on occult subjects as that of vicarious death. ${ }^{47}$ His goal is not, however he may protest, to advance knowledge or to serve humanity, but rather 'to discover some effectual method of self-preservation in the flesh to increase its pleasures ... his aims are bounded by the earthly and the sensual. ${ }^{\prime 48}$ Later, in an 1887 letter to Light, she attacked vivisection for its karmic implications, asserting that 'as a mystic and an occultist, I know [animals] are not destroyed by death,' and noting that the 'compensation' they will require in subsequent incarnations will be 'appalling.'49 Her position here is markedly different from

$45 \quad$ Ibid., 261.

46 Ibid., 26o. The two allegedly proved this cause to their satisfaction when, two years later, an anonymous student of Bernard's informed them that the great Professor had in fact died of Bright's Disease, an illness whose very conditions, exults Maitland, 'he had chiefly endeavoured to investigate by inducing ... in animals.' (261). The karmic case seemed thus closed.

47 Kingsford, 'Violationism; or Sorcery in Science', 56.

48 Ibid., 56 .

49 Kingsford, 'Animals and Their Souls', 162. Kingsford's conviction in the immortal nature of animal souls and their participation in karma is further reflected in Anna Kingsford, in which Maitland records a séance in which the pair were allegedly contacted by the spirit of a $\operatorname{dog}(\mathrm{I}, 148)$. 
that of other, more secular anti-vivisectionist feminist contemporaries such as Frances Power Cobbe, Lizzy Lind af Hageby, and Leisa Katherina Schartau who condemned the practice because it allegedly desensitized its practitioners. This rhetorical move ultimately compounded the gendered binary of affect that allowed male professionals to dismiss women as being too emotional to comment on its utility. Kingsford, by contrast, insisted that the pose of disinterested neutrality was a ruse.

For Kingsford, then, the scientific 'objectivity' claimed by the vivisectors was a form of ideological and magical enchantment, a deception conjured up by male scientists to exploit and disempower two constituencies: the animals who ended up on their dissection tables, and the women who they barred from study. This connection between sexual oppression and animal cruelty is forged allegorically rather than explicitly in 'Violationism,' which compares diabolical vivisectionists first to rapists who 'endeavou[r] to wrest ... by force' from a feminized Mother Nature 'the treasures she gives only to love,' and then to notorious sexual sadists like Gilles de Rais. ${ }^{50}$ The covert, diabolic emotionalism of such figures was to be countered, not by an impossible, objective neutrality as undesirable as it was in her view unobtainable, but rather for a morally superior form of spiritual-scientific affect, one that would replace destructive and malevolent forms of medical identity with a more empathetic and thoroughly occulted alternative. What was needed in the laboratory, she suggested, was a 'Magian, an adept in true magic' whose 'art is truly sympathetic, magnetic, and radical. ${ }^{51}$ Rather than destructively opening and probing living bodies with technical instruments, this figure would observe (both visually and psychically) and revelate, allowing karmic forces to take their course in an esoteric version of the Sydenham method. Kingsford had advocated a more secular version of this observationist approach in her 188 o doctoral thesis De L'Alimentation Végetale de l'Homme, translated and published for the British popular market one year later as The Perfect Way in Diet. A treatise on the health benefits of vegetarianism, it advances its argument through anatomical observations, anecdotal evidence, and moral and economic considerations alone, entirely eschewing experimental testing. The work is fascinatingly prefaced by a denunciation of animal sacrifice excerpted from Edwin Arnold's The Light of Asia (1879), a choice which lends to her position a distinctly eastern religious inflection, although one she would increasingly reject in her 188 os occult work. ${ }^{52}$

$50 \quad$ Kingsford, 'Violationism', 56, 57 .

$5^{1} \quad$ Kingsford, 'Violationism', 56.

$5^{2}$ For more on Kingsford's participation in the so-called "Hermetic Reaction" of the 188os, in which particular European occultists championed a specifically westernized version of 
Here and throughout her post-qualification writings, Kingsford suggests that it is better for the scientist to intuit, feel, and observe than to test and intervene. And to support this view, she would sometimes turn to the work of distinguished and decidedly non-occultist medical peers whose rejections of experimentalism she repurposed for her own esoteric anti-vivisectionist means. Thus, writing for The Nineteenth Century in 1882, she cites the words of anatomist Charles Bell (1774-1842) to assert that 'experiments have never been the means of discovery and a survey of what has been attempted in late years in physiology will prove that the opening of living animals has done more to perpetuate error than to confirm the just views taken from the study of anatomy and nature. 53 It is notable, of course, that to find such statements from fellow medical workers Kingsford had to go some ways into the past before experimentalism had reached its present settlement within European physiology. When on contemporary ground, she typically adopted a more anecdotal mode, stating, for example, that the unreliability of data obtained by vivisection was so well known at the Université de Paris, and that 'candidates preparing for the diploma are frequently warned ... to avoid basing their answers to examination' on them. ${ }^{54}$

The tricky problem posed by Pasteur's recent and indisputable success in producing a vivisectionally-produced rabies vaccine was harder to answer, but Kingsford embraced the challenge nonetheless, insisting in an 1886 letter to The Standard that one Dr John Hughes, a recently inoculated patient whose survival had been much touted, had been bitten not by a rabid dog at all, but merely one with 'acute dyspepsia. ${ }^{55} \mathrm{Had}$ he been left to recover under the observation of a physician, Hughes might, she declared, have escaped the considerable pain and danger of Pasteur's vaccine. Her position here built on her earlier rejection of the efficacy of experimentalism in cerebral localization, an endeavour whose successes she believed to have been achievable by clinical observation alone. Making this argument in the correspondence pages of The Times, she states ' $M$. Charcot and others have strenuously pointed out that nature continually presents us with ready-made experiments of the most delicate and special

esotericism in the face of the Asian-influenced philosophies of Theosophy, see Godwin, The Theosophical Enlightenment, 333-362.

53 Kingsford, 'The Uselessness of Vivisection', 173.

54 Ibid., 181. Maitland would later reiterate this claim in the anti-vivisection pamphlet he coauthored with Edward Carpenter after Kingsford's death—see Carpenter and Maitland, Vivisection, 43-44.

55 Kingsford, 'Dr John Hughes', 3. In a follow-up letter published the following week, she made a similar claim about Pasteur's first and most famous success, the young Alsatian boy Joseph Meister. See: Kingsford, 'The Case of Mr Hughes.' 
kind, which it would be impossible for mechanical artifice to realize on account of the conditions under which it is forced to work. ${ }^{56}$

Interior observation, for Kingsford, thus became the chief epistemological tool of the ethically-attuned medic and occult scientist alike, a conviction she put into practice in the acts of clairvoyant self-diagnosis and healing which Maitland presents her as periodically undertaking. His biography recounts an episode during her early years of medical study in which Kingsford treated herself for stomach pains with chloroform-laced sugar. Soon after, he writes, she passed into a 'somnambulistic state' and claimed to be able to see as if by x-ray her own intestines, where, 'between the pylorus and the duodenum,' there lay 'a small abscess filled with black matter, caused by some metallic substance which I have swallowed in my food, and which has lodged there. 57 Coming to, she then vomited up a small chip from a metal food tin that seemingly confirmed her diagnosis. Maitland reports a similar incident in the early 188os when Kingsford, already suffering from the tubercular symptoms that would kill her, was resting in Nice after some anti-vivisection campaigning in Switzerland. Slipping again into a trance, she spoke suddenly 'in a tone,' Maitland writes, 'loud, strong, firm, and peremptory as that of a man accustomed to command,' demanding that she be prescribed 'chloroform, only chloroform; no stimulants; not tea, coffee, nor brandy ... The left lung is hopelessly diseased ... She has tubercule in the lungs, the stomach, in the intestine, and in the kidneys ... This cannot be cured. ${ }^{58}$ Unable to find a local physician who would prescribe the drug in the quantities demanded by her spirit interlocuter, Kingsford herself wrote the requisite prescription, claiming to have no memory of doing so when she regained her normal consciousness. This enchanted prescription of anaesthesia, Maitland claims, allowed the patient to make it through the rest of the winter in relative comfort.

The inward-looking observationism that Kingsford advocated in her popular medical writing, anti-vivisectional campaigning and acts of clairvoyant selfdiagnosis alike reached its apotheosis in her late-life visionary writing, a corpus produced by the intuitive acts of spontaneous revelation which it simultaneously lauded. Here, perhaps more than in any of her other spheres of action, she recognized the priority of the situated self-or rather, multiple, reincarnated selves - as supreme epistemic agent, gathering knowledge through intuition, the 'capacity,' as David Myers defines it, 'for direct knowledge, for immediate

$56 \quad$ Kingsford, 'Surgery and Vivisection', 7.

57 Maitland, Anna Kingsford I, 62.

$5^{8}$ Ibid., II, 90-91. 
insight, without observation or reason.59 From the late 1870 on onwards, Kingsford and Maitland had been working together to perfect their intuitive capacity through the production of The Perfect Way (1882), a work of Hermetic Christian exegesis written via 'the operation of the mind' which allowed the pair to 'gain access to the interior and permanent region of our nature, and there to possess ourselves of the knowledge which in the long ages of her past existences the soul has made her own. 60 Two things stand out in this opening statement of method from the book's introduction. First of all, it rejects the terminology and pose of test mediumship: although Kingsford and Maitland visited spiritualist mediums, they eschewed this label themselves, and their revelatory work had nothing to do with the empirical authentication procedures, testable 'hits,' personal messages, or carefully arranged conditions associated with contemporary séance practices. Nor, although they constantly met and read at the British Museum Library, did they wish The Perfect Way to be seen as the product of research. ${ }^{61}$ Second, their prefatory remarks position the Soul and its intuitive episteme as distinctly feminine, standing in sharp opposition, as they later suggest, to the inferior and -in a fascinating reversal of surrounding figurations-distinctly masculine processes of contemporary spirit mediumship that reduced contact with the numinous to crude and dangerous experimental theatre. Far from being a place of feminine, and hence, in their view, superior knowledge formation, the séance room is in The Perfect Way presented as a misogynistic space in which elementary spirits worked for 'the systematic depreciation of women.' ${ }^{\prime 2}$ From their Theosophically-inflected perspective, the entities who knocked, materialized, and turned tables there were never the actual spirits of the dead, but 'astrals. ... especially ... bitter against the "Woman", for 'in her intuition of Spirit, they recognized their chief enemy.' ${ }^{63}$ Thus the séance room came to partner with the vivisectional theatre as a destructive masculine space to be targeted by Kingsford's explicitly feminine scientific epistemology, one that sought interspecies liberation by embracing rather than suppressing the subjective intuition of trained investigators.

59 Myers, Intuition: Its Powers and Perils. 1.

6o Kingsford and Maitland, The Perfect Way, 3.

61 Maitland, Anna Kingsford I, 286, 434, 455.

62 Ibid., 84.

63 Ibid., 78-79. 
In the early 1870 s, Kingsford had enrolled at the Université de Paris precisely in order to gain the professional authority that would allow her to be recognized as a legitimate contributor to and equal combatant in debates about the ethics and methods of medical research. Over one hundred and fifty years later, her goal remains unevenly realized. Although by the time of her death in 1888 she become one of the most ambitious and vocal of Britain's scientifically-trained occult believers, her efforts to synthesize science and spiritualism were not, and have rarely ever been recognized alongside similar attempts by distinguished scientific practitioners such as Oliver Lodge, William Crookes, Alfred Russel Wallace, and others. She and other women like her need to be recognized as equally intellectually invested, if less professionally accomplished, respondents to the shared problem of disenchantment, one whose reach we cannot fully understand without their inclusion. Kingsford's case demonstrates that women were more than bit players, sphinxes, or catalysts within the largely masculine psychodrama of psychical research. No manipulative or manipulated victim of male scientific investigators, she was herself a scientificallyeducated professional elite working actively to shape the shared conditions under which knowledge might be produced and authenticated. Further, in her insistence upon the importance of the gendered self as both agent and repository of the knowable, we can position her as an eccentric forerunner of later twentieth-century feminist epistemologists and philosophers of science. Admittedly, neither party would be pleased with the comparison, yet Kingsford's agenda surely resonates with the latter in its endeavour to articulate and defend a form of 'situated knowing,' one in which 'one's social location'-and in her case, also, karmic location-'both shapes and limits one's knowing.' ${ }^{64}$ Indeed, it is difficult to think of a better example than Kingsford's of what Elizabeth Potter describes as a key tactic of the feminist epistemology of science: namely the move to 'reject traditional assumptions that ... the epistemic agent's "situation" or "life context" is epistemically irrelevant ... that the objective epistemic agent must be politically and morally innocent and/or that knowledges requires the use of methods insuring that its production is neutral among sociopolitical and moral values. ${ }^{65}$ Never a relativist, she nonetheless, like so many of the women who experienced the institutionalized violence of medical school in the 1870 , had excellent reasons to doubt the claims of neutrality, objectivity,

64 Grasswick, 'Introduction', xvi.

65 Potter, 'Feminist Epistemology and the Philosophy of Science', 237. 
and dispassion through which her male peers sought to distinguish and elevate their methods and professional identities.

We can now revisit our two opening vignettes in the light of the larger epistemic project which I have attributed to Kingsford. Her secular critics have framed these acts of incursion, real or imagined, as evidence of her insanity or even drug addiction; ${ }^{66}$ defenders like Pert have insisted that the stories cannot possibly be true, and must only be the product of malign invention, even as they leave Kingsford's other, equally contestable beliefs unchallenged. A third possibility exists: namely that, whether they happened or not, the episodes are allegorically consistent with the intuitive methods of feminized self-scrutiny and interior revelation through which Kingsford hoped to revolutionize medical practice in the 188os. The logical endpoint of a commitment to interior observation and intuition is to put oneself on the line, to open one's own mind and, perhaps quite literally, body in order to solve an external problem. Her karmic convictions position her alleged attack on Pasteur in a similar light, as an act and effect of a situated selfhood. Realizing that the effort might rebound upon and destroy her, claims Maitland, Kingsford proceeded in case 'precisely such sacrifice of herself was required in expiation of the as yet remaining liabilities of her former lives. ${ }^{67}$ Kingsford's intuitive epistemological mandate forces us to reconsider what we think we know about the role, agency, and strategies of women involved in the spiritualism and science debates of the late nineteenth century, revealing her as anything but a naïve, marginal, or insincere player within the contests for methodological justification which pervaded her professional milieu at the fin de siècle. In foregrounding her efforts and convictions, we amplify our understanding of the authority open to (some) female participants in Britain's occultural networks, recognizing their role as equal problematizers of, rather than bystanders to, disenchantment.

\section{Bibliography}

Anonymous, 'Cures for Hydrophobia', Edinburgh Evening News 24 November 1885, 3. Asprem, E., The Problem of Disenchantment: Scientific Naturalism and Esoteric Discourse, 1900-1939, Leiden: Brill 2014.

66 The claim that Kingsford's visions were produced by the ether with which she selfmedicated her asthma can be found in Meade, Madame Blavatsky: The Woman Behind the Myth, 277 .

67 Edward Maitland, Anna Kingsford II, 246. 
Bell, E., Storming the Citadel: The Rise of the Woman Doctor, London: Constable \& Co. 1953.

Besant, A. and Leadbeater, C., Occult Chemistry: A Series of Observations on the Chemical Elements, Adyar: Theosophist Office 1909.

Bonner, T.N., To the Ends of the Earth: Women's Search for Education in Medicine, Cambridge: Harvard University Press 1992.

Burke, J., 'What Goes Around Comes Around', Scientific American 275.5 (November 1996), 125-126.

Carpenter, E. and Maitland, E., Vivisection, London: William Reeves 1893.

Daston, L. and Galison, P., Objectivity, Brooklyn: Zone Books 2007.

Fancourt, M. St. J., They Dared to Be Doctors, London: Longmans 1965.

Godwin, J., The Theosophical Enlightenment, Albany: State University of New York 1994.

Grasswick, H., 'Introduction', Feminist Epistemology and Philosophy of Science: Power in Knowledge, London: Springer 2011, xiii-xxx.

Hageby, L.L. and Schartau, L.K., The Shambles of Science: Extracts from the Diary of Two Students of Physiology, London: E. Bell 1903.

Jenkins, R., 'Disenchantment, Enchantment, and Re-Enchantment: Max Weber at the Millennium', Max Weber Studies 1.1 (November 2000), 11-32.

Josephson-Storm, J., The Myth of Disenchantment: Magic, Modernity, and the Birth of the Human Science, Chicago: University of Chicago Press 2017.

Kingsford, A., 'Animals and their Souls', Light 7 (April 1887), 161-162.

Kingsford, A., 'The Case of Mr Hughes', The Standard (22 March 1886), 3.

Kingsford, A., 'Diet: Its Moral and Spiritual Aspects', Medium and Daybreak (16 December 1881), $785^{-788 .}$

Kingsford, A., 'Dr John Hughes', The Standard (13 March 1886), 3.

Kingsford, A., 'M. Pasteur's 'Cure' of Hydrophobia', Times (9 July 1886), 4.

Kingsford, A., The Perfect Way in Diet: A Treatise Advocating a Return to the Natural and Ancient Food of our Race, London: Kegan Paul, Trench, \& Co. 1881.

Kingsford, A., 'Surgery and Vivisection', The Times (5 January 1885), 7.

Kingsford, A., 'The Sweating Cure for Hydrophobia', Pall Mall Gazette (31 March 1886), 6.

Kingsford, A., 'The Uselessness of Vivisection', The Nineteenth Century 11.6o (Feb 1882), 171-183.

Kingsford, A., “"Violationism," or Sorcery in Science', Light 2.57 (February 4 1882), 55-58.

Kingsford, A. and Maitland, E., The Perfect Way; or, The Finding of Christ, 4th Edition, London: John M. Watkins 1909.

Kottler, M.J., 'Alfred Russel Wallace, the Origin of Man, and Spiritualism', Isis 65.2 (June 1974), 145-192.

Landy, J. and Saler, M., eds, The Re-Enchantment of the World:SecularMagic in a Rational Age, Stanford: Stanford University Press 2009. 
Lansbury, C., The Old Brown Dog: Women, Workers, and Vivisection in Edwardian England, Madison: University of Wisconsin Press 1985.

Luckhurst, R., The Invention of Telepathy, Oxford: Oxford University Press 2002.

Maitland, E., Anna Kingsford: Her Life, Letters, Diary and Work, 2 Volumes, Cambridge: Cambridge University Press 2011.

Meade, M., Madame Blavatsky: The Woman Behind the Myth, New York: G.P. Putnam's Sons 198 o.

Myers, D., Intuition: Its Powers and Perils, New Haven: Yale University Press 2002.

Nelson, V., The Secret Life of Puppets, Cambridge: Harvard University Press 2001.

Noakes, R., Physics and Psychics: The Occult and the Sciences in Modern Britain, Cambridge: Cambridge University Press 2019.

Oppenheim, J., The Other World: Spiritualism and Psychical Research in England, 18501914, Cambridge: Cambridge University Press 1985.

Oxley, W., 'Egypt: and the Wonders of the Land of the Pharaohs', Medium and Daybreak (21 March 1884), 176-18o.

Palfremen, J., 'Between Scepticism and Credulity: A Study of Victorian Scientific Attitudes to Modern Spiritualism', Sociological Review 27.1 Supplement (May 1979), 237270.

Pert, A., Red Cactus: The Life of Anna Kingsford, Watsons Bay: Books and Writers 2006.

Potter, E., 'Feminist Epistemology and the Philosophy of Science', in Alcoff, Linda

Martin and Eva Feder Kittay (eds), The Blackwell Guide to Feminist Philosophy, Oxford: Blackwell 2006, 235-253.

Raia, C., The New Prometheans: Faith, Science, and the Supernatural Mind in the Victorian Fin de Siècle, Chicago: University of Chicago Press 2019.

Roberts, S., Sophia Jex-Blake: A Woman Pioneer in Nineteenth-Century Medical Reform, London: Routledge 1993.

Sera-Shriar, E., 'Credible Witnessing: A.R. Wallace, Spiritualism, and a "New Branch of Anthropology,"' Modern Intellectual History, 17 (2020), 357-384.

Shortt, S.E.D, 'Physicians and Psychics: The Anglo-American Medical Response to

Spiritualism, 1870-189o', Journal of the History of Medicine and Allied Sciences 39.3 (July 1984), 339-355.

Traini, C., The Animal Rights Struggle: An Essay in Historical Sociology, Amsterdam: University of Amsterdam Press 2016.

Viswanathan, G., '“Have Animals Souls?" Theosophy and the Suffering Body', PMLA 126.2 (March 2011), 440-447.

Weber, M., Die Protestantische Ethik und der Geist des Kapitalismus, Tübingen: Mohr 1904-1905.

Weber, M., The Protestant Work Ethic and the Spirit of Capitalism, Ed. Talcott Parsons, London: Routledge 193 .

Weber, M., 'Science as Vocation', Daedalus 87.1 (Winter 1958), 111-134. 